Article

\title{
Effect of Income Inequality on Health in Quebec: New Insights from Panel Data
}

\author{
Ibrahima Bocoum ${ }^{1, *(\mathbb{D}}$, Aurelas B. Tohon ${ }^{1} \mathbb{D}$, Roger Rukundo ${ }^{1}{ }^{\mathbb{D}}$, Catherine Macombe ${ }^{2}$ and \\ Jean-Pierre Revéret ${ }^{3}$ \\ 1 Département d'économie agroalimentaire et des sciences de la consommation, Université Laval, \\ 2425 Rue de l'Agriculture, Québec, QC G1V 0A6, Canada; bignon-aurelas.tohon.1@ulaval.ca (B.A.T.); \\ roger.rukundo.1@ulaval.ca (R.R.) \\ 2 IRSTEA, UMR ITAP-ELSA, 361 Rue Jean-François Breton, CEDEX 5, 34196 Montpellier, France; \\ catherine.macombe@irstea.fr \\ 3 Université du Québec à Montréal, École des sciences de la gestion, Case postale 8888, Succursale Centre-ville, \\ Montréal, QC H3C 3P8, Canada; reveret.jean-pierre@uqam.ca \\ * Correspondence: ibrahima.bocoum@fsaa.ulaval.ca
}

Received: 29 July 2019; Accepted: 8 October 2019; Published: 15 October 2019

\begin{abstract}
We investigated the relationship between income inequality and all-cause mortality in 87 regional county municipalities (RCMs) of Quebec (Canada) while accounting for time lags and effects of other socioeconomic variables. We presumed to be true that income inequality entails stress and depression. Thus, these phenomena were tested as mediating factors. The data used consist of eight (8) area-based chronological variables: mortality rate, Gini index, disposable income, criminality rate, number of physicians, density of population, and the proportion of people reporting feeling stressed or depressed. The association between income inequality and mortality was analyzed using the generalized method of moments (GMM) approach with local fixed effects to control unobservable characteristics. Our results show that higher income inequality led to a significant increase of mortality rate with a time lag of 5 years when socioeconomic characteristics were held constant. As expected, households' disposable income and mortality rate were negatively associated. Moreover, mortality rate was positively associated with population density and negatively associated with the number of physicians. Finally, only depression showed the potential to act as a mediating factor. Based on our findings, we suggest that, over time, income inequality, by amplifying depression phenomena, increases the mortality rate in Quebec's RCMs.
\end{abstract}

Keywords: income inequality; health; mortality; mediating factors; panel data; Quebec

\section{Introduction}

Several characteristics of a society can influence the health status of its populations: poverty, poor living conditions with a high level of material and social deprivation, unemployment, poor quality of housing, limited access to health services, and a poor quality of environment [1,2]. Economic growth was an important source of wealth in many countries at the end of the Second World War. But for three decades, it has generated deep social inequalities. In developing countries, there is a strong evidence that some phases of urbanization are responsible of deepening the inequalities [3], but the generation of inequalities by wealth increase is obvious even in rich countries $[4,5]$. In Canada, Pampalon et al. 2010 showed that material and social deprivations (instruction, employment, income, living alone, etc.) of one part of the population have a negative significant effect on survival [6]. Unfortunately, little is known about the effect of relative deprivations on health. Income inequality, for example, is presented by many researchers as the major socio-economic and non-medical determinant of health. However, 
the empirical evidence of the nature of the relationship between income inequalities and health has not yet been definitively established [7-9]. A recent study by Tang et al. 2019 in China underlines the high contribution of income inequalities to the pro-rich distribution of health information seeking (that entails better health state) [10]. Several studies tried to estimate the relationship between income inequality and population health at national and various subnational scales. The earliest paper on mortality and income inequality - 40 years ago-showed an association between Gini coefficients and both infant mortality and life expectancy at age of 5 among a group of 56 developed and developing countries [11]. By 2006, this association was confirmed through a meta-analysis on income inequality and health that reviewed analyses from 168 papers. The overwhelming majority were supportive $(70 \%)$, suggesting that health is less good in societies where income differences are bigger and others (30\%) were unsupportive or partially supportive [12].

The vast majority of studies on the subject focused on the national scale and small areas (neighborhoods, parishes, Zip codes and communities). Recent studies carried out at municipalities, provinces, and other local communities scales showed a negative association between income inequality and individuals' self-rated health (often used as a proxy of population health) [13-17]. This relationship might be stronger in the most unequal societies, as reported by Kondo et al. 2012 [17], but it remains significant even within the most egalitarian societies such as in Sweden [18]. In Canada, Laporte and Ferguson (2003) and Daly et al. 2001, focusing on provincial and national levels, found respectively, no association and a positive relationship between the Gini index and all-cause mortality and homicide rate $[19,20]$. Veenstra (2003), using a cross-sectional analysis among 24 coastal communities in British Columbia, found that inequality was positively and significantly related to the crude mortality rate, but was not significantly related to the age-standardized mortality rate [21]. In Hou and Myles (2005), a negative correlation was found between neighborhood income inequality and average health status at the neighborhood level [22]. Auger et al. 2009, using a dataset on health center regions of Quebec, found that a higher income inequality was not associated with a higher risk of mortality (Mortality rate is used as a proxy for population health) [23].

These divergent results in Canada might be explained by the insufficiency or the cross-sectional nature of the data used by most of the authors. For instance, Leigh et al. 2009 stated that cross-sectional relationships are likely to provide biased estimates of how income inequality affects health since income inequality and health may have common causes [24]. Furthermore, several previous studies have not clearly tested specific mechanisms linking income inequality to health. Although the literature is abundant on the general question of whether the relationship exists or not, much less is known about the real mechanisms in different contexts, and debates are still ongoing about the factors that best explain the link between income inequality and health. Beyond those debates, it is possible that the relevant mechanisms depend on the context. Understanding the mechanisms in different contexts would be of great help in implementing effective public policies to mitigate the effect of inequalities on health.

Epidemiologists and social scientists have proposed some theories explaining the link between income inequality and health. Leigh et al. 2009, for instance, grouped them into three categories. In the relative income mechanism, also referred to as the psychosocial mechanism, holding individual income constant, people's health can be affected if they compare their own income and life with those of others [24]. In other words, this mechanism comes from people's perception of their place in the social hierarchy based on the relative position with respect to income [25-28]. According to Wilkinson (2006), this perception can generate a feeling of deprivation or disadvantage, which in turn can generate negative mental states such as anxiety, stress, and depression that are detrimental to health [12].

The second mechanism described by Leigh et al. 2009 is the society-wide effects of inequality. These include, among other things, violent crime and public spending. According to the authors, if violent crime accounts for a tiny fraction of all deaths in developed countries, its second-order effects on mortality through increased chronic stress because of the fear of being a victim, are very important [24]. On the other hand, the value of public goods and services may decline for some citizens as income 
inequality increases, which could ultimately reduce government spending on health or education. Some circumstances, such as the fact that the rich gain more political influence, may also lead to a reduction of government spending [24]. Income inequality can finally make people feel less confident, whereas low levels of trust can lead to fewer friendships, which is itself correlated to higher age-specific mortality [24]. In a radical way, Lynch et al. 2000 developed the neo-materialist interpretation. They criticized the psychosocial mechanism and argued that health problems result from a combination of negative exposures and lack of resources, along with underinvestment in public infrastructures and services, regardless of income inequality [26]. In other words, the association between income inequality depends on the material conditions that affect population health independently of the above-mentioned psychosocial factors. However, this interpretation was challenged by Marmot and Wilkinson (2001) shortly after. According to these authors, recognizing that the socioeconomic structure has powerful psychosocial as well as material effects means that it is more, not less, important to identify and tackle the structural issues of the association between income inequality and health. In addition, this calls for urgency because psychosocial factors, unlike many direct effects of material factors, exacerbate other social problems, including levels of violence and the gradient in educational performance [29].

A third mechanism, the absolute income interpretation, suggests a statistical artifact in the association between income inequality and health. Indeed, proponents of these visions explain that the aggregate level associations between income inequality and health reflect simply the non-linear effect of individual income on health, the income elasticity of health being much higher for the poor than for the rich $[26,27]$. At a constant mean income, transfers from rich individuals to poor ones will significantly improve the health of the latter, while affecting very little the former. Therefore, less inequality within the society should improve population health [24] and when individual income is accounted for, we should not observe any significant association between income inequality and health [27].

Our study was set in the general framework of the psychosocial interpretation. In fact, we know from Caron and Liu (2010) [30] that major depression is the most prevalent mental disorder in the Canadian population and that French speakers and Quebec residents demonstrate higher rates of psychological distress. In addition, the prevalence of high psychological distress was found to be $50 \%$ higher for low-income populations than for higher-level-income populations [30], suggesting a possible pathway between the increase of income inequality, some psychosocial mediating variables, and poor health. We intended to answer the following questions: Is there any effect of income inequality on health in Quebec? If so, what would explain this effect of income inequality on health in Quebec? Is taking into account the society-wide effects of income inequality sufficient to mitigate this effect? If not, to what extent do psychosocial factors count?

The study objective was, therefore, to test the existence of these psychosocial mechanisms in 87 regional county municipalities (RCMs) of Quebec. RCMs are administrative units that ensure regional management of local municipalities that have power of jurisdiction and regulation. They carry out several missions, such as spatial planning and support to local development centers [31]. According to some authors, such as Rostila et al. 2012, in administrative entities with political autonomy, the effect of income inequality on health is mainly expected through investments in public goods and services [18].

As explained above, we took for granted the idea that income inequality is the source of stress and depression and we tested the following hypotheses: H1-there is an association between health and income inequality even after controlling other socioeconomic and material conditions in the society; H2-the association between health outcomes and income inequality is mediated by stress and depression.

We propose to re-examine the relationship between income inequality and health, using all-cause mortality rate as a proxy of health and panel data instead of commonly used cross-sectional data known to provide biased results. 


\section{Materials and Methods}

\subsection{Materials (Data and Variables)}

To investigate the relationship between income inequality and all-cause mortality, relevant data were collected from the Institute of Statistics of Quebec, the Ministry of Public Security of Quebec and Statistics Canada (Canadian Community Health Survey-CCHS). They relate to 87 regional county municipalities (RCM) of Quebec and cover a period of 12 years (2002 to 2013). The variables used (Table 1) can be grouped into three categories: principal variables (mortality rate and income inequality), psychosocial mediating variables (stress and depression), and variables relating to socioeconomic and material conditions in the society (which serve to control other possible pathways from income inequality to mortality).

Table 1. List of variables.

\begin{tabular}{|c|c|c|c|}
\hline Variable & Abbreviation & Brief Description & Sources of Data \\
\hline \multirow[t]{2}{*}{$\begin{array}{l}\text { Principal } \\
\text { variables }\end{array}$} & Gini & Gini index & $\begin{array}{l}\text { Institute of Statistics of Quebec (ISQ): Data } \\
\text { compiled by the Directorate of Economic } \\
\text { Statistics and Sustainable Development } \\
\text { from various sources (ISQ, Revenu Quebec). }\end{array}$ \\
\hline & Mortality_rate & $\begin{array}{l}\text { Number of deaths per } \\
1000 \text { inhabitants }\end{array}$ & $\begin{array}{l}\text { Institute of Statistics of Quebec (ISQ): } \\
\text { Register of demographic events }\end{array}$ \\
\hline \multirow[t]{2}{*}{$\begin{array}{l}\text { Mediating } \\
\text { variables }\end{array}$} & Stress & $\begin{array}{l}\text { Proportion of people } \\
\text { who declare that their } \\
\text { days are stressful }\end{array}$ & $\begin{array}{l}\text { Statistics Canada: Canadian Community } \\
\text { Health Survey (CCHS) }\end{array}$ \\
\hline & Depression & $\begin{array}{l}\text { Proportion of people } \\
\text { who declare feeling } \\
\text { depressed }\end{array}$ & $\begin{array}{l}\text { Statistics Canada: Canadian Community } \\
\text { Health Survey (CCHS) }\end{array}$ \\
\hline \multirow[t]{4}{*}{$\begin{array}{l}\text { Control } \\
\text { variables }\end{array}$} & Dispo_income & Disposable income & $\begin{array}{l}\text { Institute of Statistics of Quebec (ISQ): Data } \\
\text { compiled by the Directorate of Sectoral } \\
\text { Statistics and Sustainable Development } \\
\text { from various sources (ISQ, AADNC, CSST, } \\
\text { MAMROT, RRQ, SAA, SAAQ and SC) }{ }^{1}\end{array}$ \\
\hline & Criminality & $\begin{array}{l}\text { Number of provincial } \\
\text { offenses per } 100,000 \\
\text { inhabitants }\end{array}$ & $\begin{array}{l}\text { Ministry of Public Security of Quebec: Data } \\
\text { collected by municipal police force, Quebec } \\
\text { safety \& other bodies and aboriginal } \\
\text { policing }\end{array}$ \\
\hline & Density & $\begin{array}{l}\text { Number of people per } \\
\text { square kilometer }\end{array}$ & $\begin{array}{l}\text { Institute of Statistical of Quebec (ISQ): } \\
\text { Register of demographic events }\end{array}$ \\
\hline & Physicians & $\begin{array}{l}\text { Number of physicians } \\
\text { per } 1000 \text { inhabitants }\end{array}$ & $\begin{array}{l}\text { Institute of Statistics of Quebec (ISQ): Data } \\
\text { collected from the Registry of the Quebec } \\
\text { governance of health insurance }\end{array}$ \\
\hline
\end{tabular}

\footnotetext{
${ }^{1}$ Institut de la statistique du Québec (ISQ), Affaires autochtones et Développement du Nord Canada (AADNC), Commission de la santé et de la sécurité du travail (CSST), Emploi et Développement Social Canada, ministère des Affaires municipales, des Régions et de l'Occupation du territoire (MAMROT), ministère de l'Enseignement supérieur, de la Recherche, de la Science et de la Technologie, Office de la sécurité du revenu des chasseurs et piégeurs cris, Régie des rentes du Québec (RRQ), Revenu Québec, Secrétariat aux affaires autochtones (SAA), Société de l'assurance automobile du Québec (SAAQ), Statistique Canada (SC).
}

\subsubsection{Principal Variables}

Authors like Benyamini (1997) argued that self-rating represents an irreplaceable and independent dimension of health status and that an individual's health status cannot be assessed without self-rated health [32]. Others like McGee et al. 1999 reported that a self-report of fair or poor health was associated with at least a two-fold increased risk of mortality in the United States [33]. As we were not able to 
find the values of other potential dependent variables, mortality rate is used here as a suitable proxy for health status.

Although disability-adjusted life expectancy (DALE) was adopted in World Health Report 2000 as the preferred and more comprehensive measure of population health, Reidpath and Allotey (2003) recognized that mortality rate remains a good proxy of population health for countries with a mortality rate of less than 10 per 1000 inhabitants, such as Canada [34].

As for the Gini index, it is calculated using the employment income of workers aged 25-64. It is the most common income inequality measure in economics [35] and usually the only one for which panel data are available. This index was formally defined by Kondo et al. 2012 as "half of the arithmetic average of the absolute differences between all pairs of incomes within the sample, with the total then being normalized on mean income. If incomes are distributed completely equally, the value of the Gini will be zero. If one person has all the income (complete inequality) the Gini will assume a value of 1" [17]. The index is sometimes expressed as a percentage by multiplying it by 100 .

\subsubsection{Psychosocial Mediating Variables}

To suggest that a relationship is causal means predicting a subsidiary hypothesis regarding a mediating mechanism. To do so, a testable prediction of a causal mechanism has to be suggested [9]. On causal relationship between income inequality and health, several published papers suggested that mental illness is more common in more unequal societies [36,37].

In this study, we tested Stress (the proportion of people who declare that their days were stressful) and Depression (the proportion of people who declare that they felt depressed) as mediating variables. As already mentioned, in Quebec, psychological distress is significantly higher for low-income populations than for higher-level-income populations [30].

It is acknowledged in the literature that income inequality can generate feelings of deprivation and disadvantage, which generate mental pressures such as stress, frustration, depression, anxiety, as well as unhealthy behaviors (abuse of tobacco, alcohol and drugs); it may also cause a lack of social and emotional cohesion and a lack of social support, which are harmful to health $[25,27,28]$. Moreover, according to Dickerson and Kemeny (2004), what matters most are uncontrollable threats to one's social esteem, value, and status [38]. Indeed, as supported by Marmot (2005), a low social status is stressful because it reduces people's control over their lives and work. Other scholars have argued that a low social status is stressful because people are made to feel looked down on, devalued and inferior [38,39]. Both suggestions were borne out by a review of the most salient stressors affecting cortisol responses [38].

Data on stress were collected in the Canadian Community Health Survey (CCHS) using the following question: "Would you say that most of your days (in the last 12 months) were: 1-not at all stressful, 2-not so stressful, 3-a little stressful, 4-quite stressful or 5-extremely stressful?" The answers were recoded to be binary (Yes $=3,4$ or $5 ; \mathrm{No}=1$ or 2). For depression, the question was: "During the past 12 months, did you feel sad, melancholy or depressed for a period of 2 consecutive weeks or more? 1-Yes, 2-No."

To obtain the data on stress profile and depression, we are quite aware that the real measures should be based on clinical and physiological data tracking the profile of stress hormones such as adrenaline or cortisol $[40,41]$. Nevertheless, the data we used are not imprecise or inadequate. In fact, the methodology used to collect them is close to PSS (perceived stress scale), which has been proven to have significant reliability and validity [42]. Other recent studies, such that of Matthew and Brodersen (2018), have used similar data. The authors extracted the data from the annual health telephone surveys implemented by the United States' Centers for Disease control and Prevention between 2006 and 2014.

The stress and depression variables used in this study correspond to the proportions of people of the RCMs who reported being stressed or suffering from depression. By controlling other variables (presented in the next section) that were recognized in the literature as determinants of mortality, we assumed an aggregated correlation between stress, depression, and mortality rate to reflect possible 
relationships at an individual level. While correlation at aggregated level cannot replace individual level analyzes, we think that the results obtained from aggregated analyses can provide interesting insights especially if one takes into account the fact that several studies already showed that people suffering from psychological distresses have higher heart attacks and mortality rates [43-46].

Data for stress and depression were obtained for all years except 2002, 2004, 2006, 2008, and 2011. The missing information were estimated assuming a geometric inter-annual progression of the phenomenon. The progression of the phenomenon was set in order to follow a constant average growth rate.

\subsubsection{Other Variables Relating to Socioeconomic and Material Conditions in the Society}

Control variables, which represent other possible mechanisms linking income inequality to heath, were added in our analyses to better disentangle the independent effect of income inequality through stress and depression. These variables are aggregated disposable income (taking into account public transfers to people), crime rate, and number of physicians. All the variables that are commonly used to assess socio-economic status that affect populations health [9,47-52] are also related to the society-wide effect of income inequality described by Leigh et al. 2009 [24]. In addition to these other possible mediators, we controlled the population density, which has also been reported to affect the population health.

The Institute of Statistics of Quebec (ISQ) defines disposable income (Dispo_income) as an aggregate indicator at the household level that captures the macroeconomic dynamics of a territory and allows comparisons. It is the sum of all incomes received by households (wages, business income, property income, transfers such as employment insurance, social assistance, etc.), minus the transfers of households to different institutions (contributions to health and pension plans, social insurance, taxes, etc.). This amount, which takes into account the public spending on social protection, is what remains available to individuals for their final consumption of goods and services and for voluntary savings. The literature indicates that income has a large salutary effect on health. Ettner (1996) for instance, found that increases in income significantly improved mental and physical health (with strong evidence) but increased the prevalence of alcohol consumption (with little evidence) [53].

Criminality rate (Criminality) is expressed in the number of provincial offenses per 100,000 inhabitants. This variable is associated to income inequality and impacts population health. Results from Brush (2007) and Chintrakarn (2012) showed that income inequality was positively associated with crime rates in the cross-sectional analysis (moving from a county to another one) but negatively associated with crime rates in the time-series analysis (change in income inequality). In the same vein, in high crime-rated regions, fear of crime was associated with poorer mental health and lower quality of life. Curtailed physical and social activities helped explain the link between fear of crime and health [54].

Physician supply (Physicians) is expressed as the number of physicians per 1000 inhabitants. Lee (2010) reported that the supply of primary care physicians was associated with improved health outcomes, especially in chronic diseases and cancer: a higher number of primary care physicians was associated with lower all-cause mortality, cancer mortality, and cardiovascular mortality. However, the ratio of primary care physicians to specialists was not related to all-cause mortality [55]. Ho (2014), assessing the association between county-level surgeon density in British Columbia (Canada) and esophageal and gastric cancer mortality, found than the latter was more susceptible to the benefits of increased surgeon density [56].

Population density (Density) is usually measured as the number of people per square kilometer. Meijer et al. 2012, found that high population density was significantly associated with a higher mortality: residence in areas with high population density increased all-cause mortality for all age groups [57,58]. In Beenackers et al. 2018 and Nakaya et al. 2014, higher population density was found to be modestly related to higher mortality at the neighborhood and city levels $[59,60]$. 
To avoid multicollinearity among these socioeconomic variables, a correlation analysis was conducted (Table 2). The population density was highly correlated with the disposable income (coefficient of correlation superior to 0.8). We performed a VIF (variance inflation factor) test with and without the population density (results are reported in Appendix A). Although the average value of the VIF remained under 2, which is often used as the threshold for establishing a possible multicollinearity bias [61], adding the density of population significantly increased the VIF (from 1.20 to 1.56). Subsequently, we performed regressions with and without this variable.

Table 2. Pearson's correlation matrix.

\begin{tabular}{|c|c|c|c|c|c|c|c|c|}
\hline & Mortality_Rate & Gini & Dispo_Income & Criminality & Physicians & Density & Stress & Depression \\
\hline Mortality_rate & 1.0000 & & & & & & & \\
\hline Gini & 0.1409 * & 1.0000 & & & & & & \\
\hline Dispo_income & -0.4490 * & $-0.0992 *$ & 1.0000 & & & & & \\
\hline Criminality & 0.0903 * & -0.0263 & -0.0278 & 1.0000 & & & & \\
\hline Physicians & 0.2010 * & 0.0482 & $-0.4198 *$ & 0.0375 & 1.0000 & & & \\
\hline Density & -0.4037 * & $-0.0879^{*}$ & 0.8356 * & -0.0950 * & $-0.3815^{*}$ & 1.0000 & & \\
\hline Stress & 0.0160 & -0.0045 & $0.2163 *$ & 0.2923 * & -0.0113 & 0.1062 * & 1.0000 & \\
\hline
\end{tabular}

Note: $\left(^{*}\right)$ Significant at $5 \%$. The calculations are performed with Stata ${ }^{\circledR}$.

Table 3 shows descriptive statistics of the selected variables. The mean annual mortality rate and mean Gini index across the RCMs are respectively 8 per 1000 and 38.8 percent (with coefficients of variation (CV) of $23.6 \%$ and $5.9 \%$ respectively). These figures seem higher in comparison to the whole country of Canada over the same period (2002-2013). The mortality rate in Canada was about 7.1 per 1000 according to Statistics Canada (Statistics Canada, Table 13-10-0392-01 Deaths and age-specific mortality rates, by selected grouped causes), while the Gini index was about 36.9 according to the World Income Inequality Database (UNU-WIDER, World Income Inequality Database 3.4). The average annual disposable income over the study period was 920.4 million Canadian dollars (with a CV of 97.6\%). About 93.4 offenses per 100,000 inhabitants were reported annually. Inter-annual variation of these committed offenses was very high (CV is $70.9 \%)$. The average number of physicians was almost two per 1000 inhabitants, with a CV of $28.4 \%$ while the density of the population was almost 57.4 persons per square kilometer, with a very high CV of 210.3. Southern RCMs of Quebec's provinces are more populated than the northern ones. Finally, the proportion of people who declared their days as stressful and the ones who declared feeling depressed were, respectively, 19.9\% and 25.4\% (with $25.6 \%$ and $39 \%$ as respective $\mathrm{CV}$ ).

Table 3. Descriptive statistics of the selected variables.

\begin{tabular}{cccccc}
\hline Variable & Mean & Coefficient of Variation (in \%) & Min. & Max. & N \\
\hline Mortality_rate & 8.0 & 23.6 & 1.0 & 13.9 & 1044 \\
Gini & 38.8 & 5.9 & 33.5 & 49.9 & 1044 \\
Dispo_income & 920.4 & 97.6 & 80.7 & 4991.6 & 1044 \\
Criminality & 93.4 & 70.9 & 0 & 462.4 & 1044 \\
Physicians & 1.9 & 28.4 & 1.3 & 3.5 & 1044 \\
Density & 57.4 & 210.3 & 0.05 & 765.8 & 1044 \\
Stress & 19.9 & 25.6 & 9.1 & 27.1 & 1044 \\
Depression & 25.4 & 39.0 & 11.2 & 73.0 & 1044 \\
\hline
\end{tabular}

\subsection{Methods}

\subsubsection{Quantifying the Correlation between Income Inequality and Mortality Rate}

The modeling approach was built on the panel data analysis techniques described by Ahn and Schmidt (1995), Blundell and Smith (1990) and Greene (2011) [62-64]. 
We started by testing the nature of the effects associated to each individual (here, each RCM). To do so, we performed a Hausman test (Appendix B), which led us to model the effects as fixed rather than random. Fixed effects may mask or reduce the effect of income inequality on mortality as other unobservable specific characteristics of the geographical areas considered are automatically taken into account [65]. However, in our case, it was rather an advantage because we sought to control the maximum characteristics of RCMs to better capture the effect of stress and depression.

Further tests on the residuals of the model were performed to check whether the ordinary least square estimator (OLS) was suitable. The tests revealed the heterogeneity and autocorrelation of the residuals (Appendices $C$ and $D$ ), which are symptomatic of endogeneity of regressors and bias on the OLS estimator. Authors like Leigh et al. 2009 pointed to a link between income inequality and health in both directions. The reverse effect of poor health on income inequality has been less studied, but plausible hypotheses stated that poor health undermines school performances and labor market competitiveness, reducing income [24]. This simultaneity effect is a potential source of endogeneity, but the mechanisms explaining the effect of health on economic inequality do not really hold for a proxy variable such as mortality rate. Therefore, the problem of endogeneity could come from a missing third factor acting on both variables.

To take into account the local fixed-effects and deal with the above-mentioned problems, we used the generalized method of moments (GMM) approach. This method is indeed particularly adapted to panels data characterized by fixed effects, few time periods, many individuals, and autocorrelation of the residuals. [66,67]

The dynamic model can be written as follows:

$$
Y_{i t}=\alpha+\beta_{1} Y_{i(t-1)}+\beta_{2} X_{i t}+\gamma Z_{i t}+\mu_{i}+\eta_{i t}
$$

where:

$Y_{i t}$ is the mortality rate of RCM $i$ at time $t$

$X_{i t}$ is the Gini index of RCM $i$ at time $t$

$Z_{i t}$ is a vector of the mediating and control variables

$\mu_{i}$ represents the fixed effects linked to RCM $i$

$\eta_{i t}$ is the error term

$\alpha, \beta_{1}, \beta_{2}$ and $\gamma$ are the estimated parameters

We tried different time lags in order to find the delay between the variation of income inequality and its effect on the mortality rate.

To implement the GMM regressions, we ran under Stata ${ }^{\circledR}$ the xtabond 2 command developed by Roodman (2009) [67]. To deal with fixed effects and the endogeneity of regressors, we chose the system GMM specification, which combines equations in levels to equations in first difference. First differencing copes with fixed effects and different lags of the regressors that proved to be good instruments were used to cope with endogeneity problem. It is indeed possible to include all valid lags of the untransformed variables as instruments [68]. Finally, to deal with panel autocorrelation, robust standard covariance matrixes were used.

\subsubsection{Analyzing Stress and Depression as Mediating Factors}

The role of stress and depression as mediating factors was tested in two stages following Baron and Kenny (1986) [68]. In the first stage, we tested whether these two variables would vary with income inequality. We performed this test by controlling for the average disposable income and the criminality rate, which may affect stress or depression $[49,51,52,69,70]$.

In the second stage, we tested whether the introduction of the two variables in the dynamic model would modify or cancel the effects of income inequality on mortality. Specifically, we intended to see if (i) income inequality would affect the mediating factors, (ii) the mediating factors were significant 
in the dynamic model, and (iii) their introduction in the dynamic model would reduce or cancel the effects of income inequality on mortality.

In case these conditions are observed, we assumed that those factors seemed to really act as mediating factors in the potential pathway from income inequality to mortality.

\section{Results and Discussion}

Columns 1 and 2 of Table 4 show the results of the regressions of mortality rate on all the selected variables except stress and depression. These two columns present the results with and without the population density variable, which could potentially introduce a multicollinearity bias because of its high correlation with the disposable income.

Table 4. Results of the regressions of mortality rate on income inequality without and with the mediating variables.

\begin{tabular}{|c|c|c|c|c|}
\hline \multirow[b]{2}{*}{ Variable } & \multicolumn{4}{|c|}{ lMortality_Rate } \\
\hline & $\begin{array}{l}\text { Regression } \\
\text { without } \\
\text { Mediating } \\
\text { Variables (1) }\end{array}$ & $\begin{array}{l}\text { Regression without } \\
\text { Mediating Variables } \\
\text { and the Density } \\
\text { Variable (2) }\end{array}$ & $\begin{array}{l}\text { Regression (2) } \\
\text { with the } \\
\text { Depression } \\
\text { Variable (3) }\end{array}$ & $\begin{array}{c}\text { Regression (2) } \\
\text { with the Stress } \\
\text { Variable (4) }\end{array}$ \\
\hline lMortality_rate $e_{t-1}$ & $0.80^{* * *}(0.12)$ & $0.74 * *(0.14)$ & $0.83^{* * *}(0.08)$ & $0.83^{* * *}(0.06)$ \\
\hline lGini $_{t-5}$ & $2.27 * *(1.01)$ & $2.07 * *(0.91)$ & $0.90(0.69)$ & $1.41 * *(0.66)$ \\
\hline IDispo_income $t_{t-5}$ & $-0.17^{* *}(0.07)$ & $-0.11^{* * *}(0.04)$ & $-0.07 *(0.04)$ & $-0.07^{* *}(0.03)$ \\
\hline lCriminality & $-8.23(12.51)$ & $-2.71(12.30)$ & $-3.52(9.42)$ & $-3.81(8.69)$ \\
\hline lPhysicians & $-0.05(0.06)$ & $-0.15^{* * *}(0.06)$ & $-0.09(0.06)$ & $-0.10 *(0.06)$ \\
\hline lDensity & $0.06^{* *}(0.03)$ & - & - & - \\
\hline lDepression $_{t-1}$ & - & - & $0.04 *(0.02)$ & - \\
\hline lStress $_{t-1}$ & - & - & - & $-0.01(0.04)$ \\
\hline Constant & $-8.32^{* *}(3.77)$ & $-8.03^{* *}(3.58)$ & $-3.69(2.51)$ & $-5.39 * *(2.24)$ \\
\hline $\begin{array}{c}\text { Number of } \\
\text { observations }\end{array}$ & 609 & 609 & 609 & 609 \\
\hline $\begin{array}{l}\text { Arellano-Bond test } \\
\text { for } A R(1)\end{array}$ & 0.002 & 0.003 & 0.000 & 0.000 \\
\hline $\begin{array}{l}\text { Arellano-Bond test } \\
\text { for } A R(2)\end{array}$ & 0.286 & 0.343 & 0.220 & 0.242 \\
\hline Hansen test & 0.515 & 0.608 & 0.392 & 0.637 \\
\hline
\end{tabular}

Note: All the variables are specified in logarithms. $\left({ }^{* * *}\right)$ Significant at $1 \% ;\left({ }^{* *}\right)$ significant at the $5 \% ;\left({ }^{*}\right)$ significant at $10 \%$. The number of observations shrinks because of the lags on certain variables. The $p$-value of the Arellano-Bond tests indicates no order-2 serial correlation of the residuals (null hypothesis), allowing the use of longer lags of the regressors as instruments. Lags 3-5 were used as instruments and the instruments proved to be valid ( $p$-value of the Hansen test failed to reject null hypothesis of exogenous instruments). The estimates were made with Stata ${ }^{\circledR}$.

There was a significant correlation between the level of both income inequality and disposable income and the level of the mortality rate. The mortality rate increased with increasing income inequality and decreased with increasing disposable income. The rise in the mortality rate associated with the rise in income inequality was more than proportional (elasticity coefficient is between $2.07 \%$ and $2.27 \%$ ) even after controlling for some variables related to exposures and material conditions of the populations. In comparison, the increase of disposable income had little effect on the mortality rate (elasticity coefficient is between $-0.11 \%-0.17 \%$ ). To some extent, this is in line with the assumption of Wilkinson (2010) which suggests that with regards to health problems, income inequality matters more than income level in developed countries [71]. Our hypothesis H1 cannot be rejected: there is an association between health and income inequality even after controlling for the society-wide effects of income inequality.

While these results are in line with many others [23], they differ from those of Auger et al. 2009, who found no significant effect of three indicators of income inequality (measured through decile ratio, coefficient of variation, and through the proportion of total household income received by the 
$50 \%$ least well-off) on all-cause mortality [23], at the local community level (health center regions) in Quebec. McLeod et al. 2003 also reported no significant effect of income inequality on self-rated health status at the metropolitan area level in Canada, in their study [72]. This divergence with our results might be explained by the nature of the data used. Auger et al. 2009 and McLeod et al. 2003 used cross-sectional data instead of panel data.

Moreover, both variables (income inequality and disposable income) have lagged effects (5 years lag) on the mortality rate, suggesting that these effects are not instantaneous and involve mediating factors. In addition to the 5-year lag and given the limited time series (12 years only), we also tested 0to 6-year lags, but were not able to find a statistically significant effect of income inequality on mortality rate while satisfying all the econometric specification tests (AR and Hansen tests are described in the three last rows of Table 4). Other time lags likely occurred, but we could not find them. This finding on the existence of time lags coincides with results of Blakely et al. 2000, who scanned lag time between inequality and poor self-rated health at the national level in the United States. They found possible lag effects of up to 15 years among people aged 45 years or older [73]. This could be explained by the fact that it would be easier and would take less time to perceive differences and inequalities in one's immediate environment than at the level of an entire country. Consistently with the psychosocial mechanism, if one perceives the inequality more quickly, it is very likely that the consequences in term of anxiety, stress, and depression, and ultimately the consequences on mortality, would manifest themselves more quickly. One can think that inequality could affect health more easily and quickly if people compare themselves and find a difference between themselves and others who are closer to their environment. Moreover, time lag tends to decrease after controlling for state and regional fixed effects [74].

Unlike Stafford et al. 2007, we found no significant relationship between criminality rate and mortality [54]. However, our results are not very surprising since, for the case of Quebec and Canada, the most important predictors of mortality are heavy substance use $[75,76]$ which might be under-reported to police services.

When added in the regression (Table 4, Column 1), the density of population was positively correlated to mortality. This correlation was weak since a $1 \%$ increase in density is associated with an increase of only $0.06 \%$ in mortality.

In the regression without population density (Table 4, Column 2), the number of physicians has a significant effect with a negative sign. A $1 \%$ increase in the number of physicians is associated with a decrease of only $0.15 \%$ in mortality. In $2013,24.6 \%$ of Quebec's inhabitants did not have access to a regular family doctor (Statistics Canada, Table 13-10-0484-01 Access to a regular family physician). It seems consistent that a larger number of physicians would allow individuals to have access to a family doctor, which may ultimately play a positive role on their health status and the global mortality rate.

To test depression and stress as possible mediating factors of the pathway between income inequality and mortality while avoiding any potential multicollinearity problem, we kept all the previous variables, except density of population, in the model. The test was performed in two steps. First, depression and stress were both found to be positively correlated with income inequality, with time lags of 3 and 5 years, respectively (Table 5). If there is a causal relationship, the effects of income inequality on both variables seem important. A $1 \%$ increase in income inequality is correlated with an increase in the number of people feeling depressed and stressed by $4.17 \%$ and $14.34 \%$, respectively. We were not able to obtain significant effects of income inequality on both variables using other time lags while satisfying all econometric specification tests (AR and Hansen tests are described in the six last rows of Table 5). 
Table 5. Results of the regression of stress and depression on income inequality.

\begin{tabular}{|c|c|c|}
\hline & lDepression & lStress \\
\hline lDepression $_{t-1}$ & $0.43^{* * *}(0.12)$ & \\
\hline IStress $_{t-1}$ & & $-0.90^{* * *}(0.07)$ \\
\hline lGini $_{t-3}$ & $4.17 * * *(1.06)$ & \\
\hline lGini $_{t-5}$ & & $14.34^{* * *}(2.36)$ \\
\hline Constant & $-13.47^{* * *}(3.54)$ & $-46.69^{* * *}(8.56)$ \\
\hline Number of observations & 783 & 609 \\
\hline Arellano-Bond test for AR(1) & 0.000 & 0.000 \\
\hline Arellano-Bond test for AR(2) & 0.171 & 0.000 \\
\hline Arellano-Bond test for AR(3) & & 0.063 \\
\hline Arellano-Bond test for AR(4) & & 0.076 \\
\hline Arellano-Bond test for AR(5) & & 0.348 \\
\hline Hansen test & 0.691 & 0.223 \\
\hline
\end{tabular}

Note: All the variables are specified in logarithms. Standard errors are in parentheses. $\left.{ }^{* * *}\right)$ Significant at $1 \%$. The number of observations shrinks because of the lags on certain variables. For the regression on lDepression, the p-value of the Arellano-Bond tests indicates no order-2 serial correlation of the residuals (null hypothesis) allowing the use of longer lags of the regressors as instruments. Lags 9-10 were used as instruments and these instruments proved to be valid (the $p$-value of the Hansen test failed to reject null hypothesis of exogenous instruments). As for the regression on 1 Stress, the p-value of the Arellano-Bond tests indicates no order-5 serial correlation of the residuals (null hypothesis), allowing the use of longer lags of the regressors as instruments. Lags 7-8 were used as instruments and the instruments proved to be valid (the p-value of the Hansen test failed to reject null hypothesis of exogenous instruments). The estimates were made with Stata ${ }^{\circledR}$.

Second, when depression was controlled for (Column 3 of Table 4), the correlation between income inequality and mortality weakened (the elasticity coefficient ranges from 2.07-2.27 to 0.90 ) and became statistically non-significant. If we support the idea that income inequality entails depression, this suggests that depression is potentially one of the mechanisms by which income inequality affects the mortality rate. Thus, hypothesis $\mathrm{H} 2$ cannot be rejected for depression: the association between health outcomes and income inequality is mediated by depression.

In addition, controlling for the specific variables mentioned above, depression was positively associated to mortality (elasticity coefficient is 0.04 ), with a time-lag of 1 year. We were not able to find a statistically significant association with other time lags. However, we recognized here that the use of aggregated data instead of individual data may have prevented us from accurately determining the actual time lags and the degree of association between depression and mortality.

Controlling for stress (Column 4 of Table 4) also decreased the effect of income inequality on mortality rate, but the coefficient of the stress variable is not statistically significant (Different time lags were also tested for the stress variable. None had a significant impact on the mortality rate). According to these results and following Baron and Kenny (1986), only depression can be considered here as a potential mediating factor which would connect income inequality to mortality.

Our results support those of Lopez (2004), who pointed to depressive disorder as a mechanism that connects income inequality to (poor) health [77]. These results are in line with Muramatsu (2003) and Pabayo et al. 2014, whose findings showed a positive and significant association between income inequality and depression [78,79]. Except for stress, our results also support the conclusions of several other studies, namely those of Yusuf et al. 2004, Liu et al. 2016, Nguyen et al. 2016, and that of the WHO (2018) [43-46]. Yusuf et al. 2004, in a study on 24,767 people in 52 countries, found that people who experienced several periods of stress or depression had a risk of heart attack increased by $38 \%$, compared to people who did not suffer from stress or depression [46]. According to the World Health Organization (WHO) (2018), myocardial infarction is, in Western countries, one of the leading causes of death after heart disease and cancer [45]. Liu et al. 2016 and Nguyen et al. 2016 showed that compared to non-depressed subjects, depressed people recorded the highest mortality rates [43,44]. However, Liu et al. 2016 have shown that when depressed people received adequate medical treatment, the relationship between mortality and depression disappeared [43]. 


\section{Conclusions}

In this article, we analyzed the correlation between income inequality and all-cause mortality in Quebec (Canada) using panel data and dynamic econometric modeling. Mortality rate was used as a proxy to capture health problems. Our results show a positive and significant correlation between income inequality and mortality rate at the regional county municipalities (RCM) level. In addition, our results suggest that there was a lagged effect of income inequality on population mortality, which implies transmission pathways through mediating factors.

We support the hypothesis set by many authors that depression is one of the factors of transmission of income inequality to mortality. In Quebec's RCMs, it seems that increasing the degree of relative income deprivation (income inequality) increases the number of people affected by depression, which, in turn, leads to a higher mortality rate. A time lag of 5 years is observed when the values taken by income inequality and by mortality became correlated. This time lag seems shorter for the association between depression and mortality ( 1 year). If confirmed, this suggests that the time for intervention to avoid premature death is very strained. Therefore, specific interventions for depressed people are an emergency. This might be out of the reach of public policy as it needs time to be implemented. It is urgent to find efficient ways of preventing depression, which is a widespread problem related to the characteristics and functioning of modern societies.

Nevertheless, based on the above findings, the most efficient action at the policy level would be to implement long-term measures to identify and reduce the factors that cause income inequality. For instance, supra and local authorities should put more emphasis on the economic and social integration of disadvantaged populations, such as indigenous populations and immigrants, while improving their access to adequate health insurance and services. As the apparent elasticity coefficient between income inequality and mortality is high (about 2\%), we can expect that a tiny decrease of the first (by distributing more subsidy to the less well off part of the population or by increasing the lower wages) would entail a real drop in mortality rate in the RCMs without jeopardizing the public budgets. Moreover, the bad feelings caused by inequality likely do not only depend on income inequality [71]. In addition, the influence of other inequality factors ought to be correctly accounted for.

However, our study suffers from certain limitations. For instance, because of lack of data, we were not able to highlight all the time lags between the evolutions of the values taken by the variables. These limitations are, in particular, due to lack of data to accurately address and control the influence of other socioeconomic determinants of mortality. For example, we were not able to find appropriate data on access to health insurance and services, as well as rates and levels of education corresponding to the RCM scale. This study suggests a causal pathway starting from bad feelings inspired by high income inequality and moving toward depression and eventually, premature death, at the RCMs level. Yet, many questions remain open about the variations caused by the level of analysis, the role of the political autonomy of the surveyed entities, the influence of increases and decreases of the Gini coefficient with time-lags in the same place, the other factors of inequality, the role of public goods, etc.

Further research is needed to analyze the validity of our findings for different income inequality variables and for different health problems. In order to generalize the results of this study, it would be interesting to extend this study to other Canadian provinces while considering similar scales to those of the RCMs of Quebec.

Author Contributions: Authors' initials: I.B.; A.B.T.; R.R.; C.M.; J.-P.R. Conceptualization: I.B., A.B.T., C.M., and J.-P.R.; methodology, I.B. and A.B.T.; validation, I.B., A.B.T., C.M. and J.-P.R.; formal analysis, I.B., A.B.T., and R.R.; investigation, I.B., A.B.T., and R.R.; resources, I.B., A.B.T., C.M., and J.-P.R.; data curation, I.B. and A.B.T.; writing-original draft preparation, I.B., A.B.T., R.R., C.M., and J.-P.R.; writing-review and editing, I.B., A.B.T., R.R., C.M., and J.-P.R.; visualization, I.B., A.B.T., and R.R.; supervision, I.B., C.M., and J.-P.R.; funding acquisition, I.B., C.M., and J.-P.R.

Funding: This research was funded by the young researcher support program of the Faculty of agricultural and Food Sciences of Université Laval (Quebec) and scholarships offered by the Institut de recherche en sciences et technologies pour l'environnement et l'agriculture (IRSTEA) in France and the Chaire internationale sur le cycle de vie Polytechnique Montréal/UQÀM in Quebec. 
Conflicts of Interest: The authors declare no conflict of interest. The funders had no role in the design of the study; in the collection, analyses, or interpretation of data; in the writing of the manuscript; or in the decision to publish the results.

\section{Appendix A}

Table A1. Multicollinearity tests (variance inflation factor tests).

\begin{tabular}{lcc}
\hline & VIF & VIF \\
\hline Gini & 1.04 & 1.03 \\
Dispo_income & 2.52 & 1.48 \\
Criminality & 1.11 & 1.11 \\
Physicians & 1.46 & 1.37 \\
Density & 2.55 & \\
Stress & 1.18 & 1.18 \\
Depression & 1.05 & 1.04 \\
Mean VIF & 1.56 & 1.20 \\
\hline
\end{tabular}

Note: All the variables are specified in logarithms. Tests are made with Stata ${ }^{\circledR}$.

\section{Appendix B}

Table A2. Hausman test.

\begin{tabular}{|c|c|c|c|}
\hline & \multicolumn{2}{|c|}{ 1Mortality_Rate } & \multirow{2}{*}{ b-B } \\
\hline & Fixed Effects (b) & Random Effects (B) & \\
\hline lGini & -0.5237644 & -0.4507633 & -0.0730011 \\
\hline IDispo_income & 0.1420331 & 0.0238672 & 0.1181659 \\
\hline lCriminality & 9.455 .255 & 1.441 .207 & -4.956 .813 \\
\hline lPhysicians & 0.07344 & 0.1782056 & -0.1047656 \\
\hline IDensity & -0.1656255 & -0.0220127 & -0.1436128 \\
\hline lStress & -0.0198026 & -0.0017459 & -0.0180567 \\
\hline lDepression & -0.0020765 & -0.0034886 & 0.0014121 \\
\hline
\end{tabular}

chi2 $(5)=(b-B)^{\prime}\left[\left(V \_b-V \_B\right)^{\wedge}(-1)\right](b-B)=53.84$, Prob > chi2 $=0.0000$ Note: All the variables are specified in logarithms. Tests are made with Stata ${ }^{\circledR}$.

\section{Appendix C}

Table A3. Heteroscedasticity test.

\begin{tabular}{ll}
\hline & \multicolumn{1}{c}{ Residuals 2} \\
\hline lGini & $-0.02^{* * *}(0.00)$ \\
lDispo_income & $0.06^{* * *}(0.02)$ \\
lCriminality & $206.58(133.00)$ \\
lPhysicians & $0.04(0.04)$ \\
lDensity & $-0.05^{* * *}(0.01)$ \\
lStress & $-0.02(0.03)$ \\
lDepression & $0.05^{*}(0.03)$ \\
Constant & $0.56^{* * *}(0.21)$ \\
Number of observations & 1044 \\
\hline
\end{tabular}

$\mathrm{F}(7,1036)=8.26$, Prob $>\mathrm{F}=0.0000$. Note: All the variables are specified in logarithms..$\left.{ }^{* * *}\right)$ Significant at $1 \% ;\left(^{*}\right)$ significant at $10 \%$. Standard errors in parentheses. Tests made with Stata ${ }^{\circledR}$. 


\section{Appendix D}

Table A4. Wooldridge test for serial autocorrelation in panel data.

\begin{tabular}{l}
\hline H0: No First Order Autocorrelation \\
\hline $\mathrm{F}(1,86)=5.862$ \\
Prob $>\mathrm{F}=0.0176$ \\
\multicolumn{2}{c}{ Note: Tests are made with Stata ${ }^{\circledR}}$.
\end{tabular}

\section{References}

1. Jamtsho, S.; Corner, R.; Dewan, A. Spatio-temporal analysis of spatial accessibility to primary health care in Bhutan. ISPRS Int. J. Geo-Inf. 2015, 4, 1584-1604. [CrossRef]

2. Wilkinson, R.G.; Marmot, M. Social Determinants of Health: the Solid Facts; World Health Organization: Copenhagen, Denmark, 2003.

3. Sulemana, I.; Nketiah-Amponsah, E.; Codjoe, E.A.; Andoh, J.A.N. Urbanization and income inequality in Sub-Saharan Africa. Sustain. Cities Soc. 2019, 48, 101544. [CrossRef]

4. Piketty, T. Capital in the Twenty-First Century; Belknap Press: Cambridge, MA, USA, 2014.

5. Stiglitz, J.E. Le prix de l'inégalité; Editions Les liens qui libèrent: Paris, France, 2012.

6. Pampalon, R.; Hamel, D.; Gamache, P. Health inequalities, deprivation, immigration and aboriginality in Canada: A geographic perspective. Can. J. Public Health 2010, 101, 470-474. [CrossRef]

7. Bocoum, I.; Macombe, C.; Revéret, J.-P. Anticipating impacts on health based on changes in income inequality caused by life cycles. Int. J. Life Cycle Assess. 2015, 20, 405-417. [CrossRef]

8. Lynch, J.; Smith, G.D.; Harper, S.A.; Hillemeier, M.; Ross, N.; Kaplan, G.A.; Wolfson, M. Is income inequality a determinant of population health? Part 1. A systematic review. Milbank Q. 2004, 82, 5-99. [CrossRef] [PubMed]

9. Pickett, K.E.; Wilkinson, R.G. Income inequality and health: a causal review. Soc. Sci. Med. 2015, 128, 316-326. [CrossRef] [PubMed]

10. Tang, C.; Wu, X.; Chen, X.; Pan, B.; Yang, X. Examining income-related inequality in health literacy and health-information seeking among urban population in China. BMC Public Health 2019, 19, 221. [CrossRef]

11. Rodgers, G.B. Income and inequality as determinants of mortality: an international cross-section analysisa. Int. J. Epidemiol. 2002, 31, 533-538. [CrossRef]

12. Wilkinson, R.G.; Pickett, K.E. Income inequality and population health: A review and explanation of the evidence. Soc. Sci. Med. 2006, 62, 1768-1784. [CrossRef]

13. Chiavegatto Filho, A.D.P.; Lebrão, M.L.; Kawachi, I. Income inequality and elderly self-rated health in São Paulo, Brazil. Ann. Epidemiol. 2012, 22, 863-867. [CrossRef]

14. Edvinsson, S.; Häggström Lundevaller, E.; Malmberg, G. Do unequal societies cause death among the elderly? A study of the health effects of inequality in Swedish municipalities in 2006. Glob. Health Action 2013, 6, 19116. [CrossRef] [PubMed]

15. Feng, Z.; Wang, W.W.; Jones, K.; Li, Y. An exploratory multilevel analysis of income, income inequality and self-rated health of the elderly in China. Soc. Sci. Med. 2012, 75, 2481-2492. [CrossRef] [PubMed]

16. Franzini, L.; Giannoni, M. Determinants of health disparities between Italian regions. BMC Public Health 2010, 10, 296. [CrossRef] [PubMed]

17. Kondo, N.; van Dam, R.M.; Sembajwe, G.; Subramanian, S.; Kawachi, I.; Yamagata, Z. Income inequality and health: The role of population size, inequality threshold, period effects and lag effects. J. Epidemiol. Community Health 2012, 66, e11. [CrossRef] [PubMed]

18. Rostila, M.; Kölegård, M.L.; Fritzell, J. Income inequality and self-rated health in Stockholm, Sweden: A test of the 'income inequality hypothesis' on two levels of aggregation. Soc. Sci. Med. 2012, 74, 1091-1098. [CrossRef] [PubMed]

19. Daly, M.; Wilson, M.; Vasdev, S. Income inequality and homicide rates in Canada and the United States. Can. J. Criminol. 2001, 43, 219. 
20. Laporte, A.; Ferguson, B.S. Income inequality and mortality: time series evidence from Canada. Health Policy 2003, 66, 107-117. [CrossRef]

21. Veenstra, G. Economy, community and mortality in British Columbia, Canada. Soc. Sci. Med. 2003, 56, 1807-1816. [CrossRef]

22. Hou, F.; Myles, J. Neighbourhood inequality, neighbourhood affluence and population health. Soc. Sci. Med. 2005, 60, 1557-1569. [CrossRef]

23. Auger, N.; Zang, G.; Daniel, M. Community-level income inequality and mortality in Québec, Canada. Public Health 2009, 123, 438-443. [CrossRef]

24. Leigh, A.; Jencks, C.; Smeeding, T.M. Health and economic inequality. Oxf. Handb. Econ. Inequal. 2009, 384-405.

25. Biggs, B.; King, L.; Basu, S.; Stuckler, D. Is wealthier always healthier? The impact of national income level, inequality, and poverty on public health in Latin America. Soc. Sci. Med. 2010, 71, 266-273. [CrossRef] [PubMed]

26. Lynch, J.W.; Smith, G.D.; Kaplan, G.A.; House, J.S. Income inequality and mortality: Importance to health of individual income, psychosocial environment, or material conditions. BMJ 2000, 320, 1200-1204. [CrossRef] [PubMed]

27. Qi, Y. The impact of income inequality on self-rated general health: Evidence from a cross-national study. Res. Soc. Stratif. Mobil. 2012, 30, 451-471. [CrossRef]

28. Yang, T.-C.; Chen, V.Y.-J.; Shoff, C.; Matthews, S.A. Using quantile regression to examine the effects of inequality across the mortality distribution in the U.S. counties. Soc. Sci. Med. 2012, 74, 1900-1910. [CrossRef]

29. Marmot, M.; Wilkinson, R.G. Psychosocial and material pathways in the relation between income and health: A response to Lynch et al. BMJ 2001, 322, 1233-1236. [CrossRef]

30. Caron, J.; Liu, A. A descriptive study of the prevalence of psychological distress and mental disorders in the Canadian population: comparison between low-income and non-low-income populations. Chronic Dis. Inj. Can. 2010, 30, 84-94.

31. MAMOT. Ministère des Affaires Municipales et de l'occupation du Territoire, QUEBEC. L'organisation municipale au Québec en 2016. 2016. Available online: https://www.mamh.gouv.qc.ca/fileadmin/publications/ organisation_municipale/organisation_territoriale/organisation_municipale_2016.pdf (accessed on 15 July 2019).

32. Idler, E.L.; Benyamini, Y. Self-rated health and mortality: A review of twenty-seven community studies. J. Health Soc. Behav. 1997, 38, 21-37. [CrossRef]

33. McGee, D.L.; Liao, Y.; Cao, G.; Cooper, R.S. Self-reported health status and mortality in a multiethnic US cohort. Am. J. Epidemiol. 1999, 149, 41-46. [CrossRef]

34. Reidpath, D.D.; Allotey, P. Infant mortality rate as an indicator of population health. J. Epidemiol. Community Health 2003, 57, 344-346. [CrossRef]

35. Xu, K. How Has the Literature on Gini's Index Evolved in the Past 80 Years? (April 2003); Economics Working Paper; Dalhousie University: Halifax, NS, Canada, 2003. [CrossRef]

36. Pickett, K.E.; James, O.W.; Wilkinson, R.G. Income inequality and the prevalence of mental illness: A preliminary international analysis. J. Epidemiol. Community Health 2006, 60, 646-647. [CrossRef] [PubMed]

37. Pickett, K.E.; Wilkinson, R.G. Inequality: An underacknowledged source of mental illness and distress. Br. J. Psychiatry 2010, 197, 426-428. [CrossRef] [PubMed]

38. Dickerson, S.S.; Kemeny, M.E. Acute stressors and cortisol responses: A theoretical integration and synthesis of laboratory research. Psychol. Bull 2004, 130, 355-391. [CrossRef] [PubMed]

39. Wilkinson, R.G. The Impact of Inequality: How to Make Sick Societies Healthier; The New Press: New York, NY, USA, 2005.

40. Möstl, E.; Palme, R. Hormones as indicators of stress. Domest. Anim. Endocrinol. 2002, 23, 67-74. [CrossRef]

41. Palme, R. Non-invasive measurement of glucocorticoids: Advances and problems. Physiol. Behav. 2019, 199, 229-243. [CrossRef]

42. Cohen, S.; Kamarck, T.; Mermelstein, R. A Global Measure of Perceived Stress. J. Health Soc. Behav. 1983, 24, 385-396. [CrossRef]

43. Liu, B.; Floud, S.; Pirie, K.; Green, J.; Peto, R.; Beral, V.; Collaborators, M.W.S. Does happiness itself directly affect mortality? The prospective UK Million Women Study. Lancet 2016, 387, 874-881. [CrossRef] 
44. Nguyen, D.; Duca, N.; Belnap, B.; Abede, K.; Anderson, A.; Reynolds, C.F.; Rollman, B. Depression following coronary artery bypass graft surgery predicts increded 10-years all-cause nortality. J. Am. Coll. Cardiol. 2016, 67, 2102. [CrossRef]

45. World Health Organization (WHO). The Top 10 Causes of Death. 2018. Available online: https://www.who. int/news-room/fact-sheets/detail/the-top-10-causes-of-death (accessed on 19 February 2019).

46. Yusuf, S.; Hawken, S.; Ôunpuu, S.; Dans, T.; Avezum, A.; Lanas, F.; McQueen, M.; Budaj, A.; Pais, P.; Varigos, J. Effect of potentially modifiable risk factors associated with myocardial infarction in 52 countries (the INTERHEART study): case-control study. Lancet 2004, 364, 937-952. [CrossRef]

47. Fujita, S.; Moscarini, G. Recall and unemployment. Am. Econ. Rev. 2017, 107, 3875-3916. [CrossRef]

48. Jensen, G. Taking Social Learning Global: Micro-Macro Transitions in Criminological Theory. In Social Learning Theory and the Explanation of Crime; Routledge: Abington, UK, 2017; pp. 15-44.

49. Kaminer, D.; Eagle, G.T. Interventions for posttraumatic stress disorder: A review of the evidence base. South Afr. J. Psychol. 2017, 47, 7-22. [CrossRef]

50. Mucci, N.; Giorgi, G.; Roncaioli, M.; Perez, J.F.; Arcangeli, G. The correlation between stress and economic crisis: A systematic review. Neuropsychiatr. Dis. Treat. 2016, 12, 983. [CrossRef] [PubMed]

51. Strauss, A.L. Social Psychology and Human Values; Routledge: Abington, UK, 2017.

52. Yanovich, C.; Kirby, M.L.; Michaelevski, I.; Yadid, G.; Pinhasov, A. Social rank-associated stress vulnerability predisposes individuals to cocaine attraction. Sci. Rep. 2018, 8, 1759. [CrossRef] [PubMed]

53. Ettner, S.L. New evidence on the relationship between income and health. J. Health Econ. 1996, 15, 67-85. [CrossRef]

54. Stafford, M.; Chandola, T.; Marmot, M. Association Between Fear of Crime and Mental Health and Physical Functioning. Am. J. Public Health 2007, 97, 2076-2081. [CrossRef] [PubMed]

55. Lee, J.; Park, S.; Choi, K.; Kwon, S.-m. The association between the supply of primary care physicians and population health outcomes in Korea. Fam. Med. 2010, 42, 628-635. [PubMed]

56. Ho, M.Y.; Al-barrak, J.; Peixoto, R.D.; Cheung, W.Y. The association between county-level surgeon density and esophageal and gastric cancer mortality. J. Gastrointest. Cancer 2014, 45, 487-493. [CrossRef]

57. Meijer, M.; Kejs, A.M.; Stock, C.; Bloomfield, K.; Ejstrud, B.; Schlattmann, P. Population density, socioeconomic environment and all-cause mortality: A multilevel survival analysis of 2.7 million individuals in Denmark. Health Place 2012, 18, 391-399. [CrossRef]

58. Meijer, M.; Röhl, J.; Bloomfield, K.; Grittner, U. Do neighborhoods affect individual mortality? A systematic review and meta-analysis of multilevel studies. Soc. Sci. Med. 2012, 74, 1204-1212. [CrossRef]

59. Beenackers, M.; Oude Groeniger, J.; Kamphuis, C.; van Lenthe, F. Population density and mortality in a compact Dutch city: 23-year follow-up of the Dutch GLOBE study. Eur. J. Public Health 2018, 28, cky213. 106. [CrossRef]

60. Nakaya, T.; Honjo, K.; Hanibuchi, T.; Ikeda, A.; Iso, H.; Inoue, M.; Sawada, N.; Tsugane, S.; Japan Public Health Center-based Prospective Study Group. Associations of all-cause mortality with census-based neighbourhood deprivation and population density in Japan: A multilevel survival analysis. PLoS ONE 2014, 9, e97802. [CrossRef] [PubMed]

61. Chatterjee, S.; Hadi, A.S. Regression Analysis by Example; John Wiley \& Sons: Hoboken, NJ, USA, 2015.

62. Ahn, S.C.; Schmidt, P. Efficient estimation of models for dynamic panel data. J. Econom. 1995, 68, 5-27. [CrossRef]

63. Blundell, R.; Smith, R.J. Conditions initiales et estimation efficace dans les modèles dynamiques sur données de panel: Une application au comportement d'investissement des entreprises. Annales d'Économie et de Statistique 1990. [CrossRef]

64. Greene, W. Econométrie; Schlacther, D., Azomahou, T., Van, P.-N., Raymond, W., Eds.; Pearson France: Paris, France, 2011.

65. Beckfield, J. Does income inequality harm health? New cross-national evidence. J. Health Soc. Behav. 2004, 45, 231-248. [CrossRef] [PubMed]

66. Araujo, C.; Brun, J.; Combes, J. Économétrie. 2nd éd.; Bréal, Collection Amphi Economie: Paris, France, 2008.

67. Roodman, D. How to do xtabond2: An introduction to difference and system GMM in Stata. Stata J. 2009, 9, 86-136. [CrossRef]

68. Baron, R.M.; Kenny, D.A. The moderator-mediator variable distinction in social psychological research: Conceptual, strategic, and statistical considerations. J. Personal. Soc. Psychol. 1986, 51, 1173. [CrossRef] 
69. Fazel, S.; Wolf, A.; Chang, Z.; Larsson, H.; Goodwin, G.M.; Lichtenstein, P. Depression and violence: A Swedish population study. Lancet Psychiatry 2015, 2, 224-232. [CrossRef]

70. Rözer, J.J.; Volker, B. Does income inequality have lasting effects on health and trust? Soc. Sci. Med. 2016, 149, 37-45. [CrossRef]

71. Wilkinson, R.; Pickett, K. The Spirit Level: Why Equality is Better for Everyone; Penguin: London, UK, 2010.

72. McLeod, C.B.; Lavis, J.N.; Mustard, C.A.; Stoddart, G.L. Income inequality, household income, and health status in Canada: A prospective cohort study. Am. J. Public Health 2003, 93, 1287-1293. [CrossRef]

73. Blakely, T.A.; Kennedy, B.P.; Glass, R.; Kawachi, I. What is the lag time between income inequality and health status? J. Epidemiol. Community Health 2000, 54, 318-319. [CrossRef]

74. Mellor, J.M.; Milyo, J. Is exposure to income inequality a public health concern? Lagged effects of income inequality on individual and population health. Health Serv. Res. 2003, 38, 137-151. [CrossRef] [PubMed]

75. King, N.B.; Fraser, V.; Boikos, C.; Richardson, R.; Harper, S. Determinants of increased opioid-related mortality in the United States and Canada, 1990-2013: A systematic review. Am. J. Public Health 2014, 104, e32-e42. [CrossRef] [PubMed]

76. Roy, É.; Haley, N.; Leclerc, P.; Sochanski, B.; Boudreau, J.-F.; Boivin, J.-F. Mortality in a cohort of street youth in Montreal. JAMA 2004, 292, 569-574. [CrossRef] [PubMed]

77. Lopez, R. Income inequality and self-rated health in US metropolitan areas: A multi-level analysis. Soc. Sci. Med. 2004, 59, 2409-2419. [CrossRef] [PubMed]

78. Muramatsu, N. County-level income inequality and depression among older Americans. Health Serv. Res. 2003, 38, 1863-1884. [CrossRef] [PubMed]

79. Pabayo, R.; Kawachi, I.; Gilman, S.E. Income inequality among American states and the incidence of major depression. J. Epidemiol. Community Health 2014, 68, 110-115. [CrossRef] [PubMed]

(C) 2019 by the authors. Licensee MDPI, Basel, Switzerland. This article is an open access article distributed under the terms and conditions of the Creative Commons Attribution (CC BY) license (http://creativecommons.org/licenses/by/4.0/). 